\title{
Parameterization of a ruminant model of phosphorus digestion and metabolism
}

\author{
X. Feng, K. F. Knowlton, and M. D. Hanigan ${ }^{1}$ \\ Department of Dairy Science, Virginia Polytechnic Institute and State University, Blacksburg 24061
}

\begin{abstract}
The objective of the current work was to parameterize the digestive elements of the model of Hill et al. (2008) using data collected from animals that were ruminally, duodenally, and ileally cannulated, thereby providing a better understanding of the digestion and metabolism of $\mathrm{P}$ fractions in growing and lactating cattle. The model of Hill et al. (2008) was fitted and evaluated for adequacy using the data from 6 animal studies. We hypothesized that sufficient data would be available to estimate $\mathrm{P}$ digestion and metabolism parameters and that these parameters would be sufficient to derive $\mathrm{P}$ bioavailabilities of a range of feed ingredients. Inputs to the model were dry matter intake; total feed $\mathrm{P}$ concentration $\left(f_{\mathrm{PtFd}}\right)$; phytate $(\mathrm{Pp})$, organic $(\mathrm{Po})$, and inorganic $(\mathrm{Pi}) \mathrm{P}$ as fractions of total $\mathrm{P}\left(f_{\mathrm{PpPt}}, f_{\mathrm{PoPt}}, f_{\mathrm{PiPt}}\right)$; microbial growth; amount of $\mathrm{Pi}$ and $\mathrm{Pp}$ infused into the omasum or ileum; milk yield; and BW. The available data were sufficient to derive all model parameters of interest. The final model predicted that given 75 $\mathrm{g} / \mathrm{d}$ of total $\mathrm{P}$ input, the total-tract digestibility of $\mathrm{P}$ was $40.8 \%$, Pp digestibility in the rumen was $92.4 \%$, and in the total-tract was $94.7 \%$. Blood $\mathrm{P}$ recycling to the rumen was a major source of $\mathrm{Pi}$ flow into the small intestine, and the primary route of excretion. A large proportion of $\mathrm{Pi}$ flowing to the small intestine was absorbed; however, additional $\mathrm{Pi}$ was absorbed from the large intestine $(3.15 \%)$. Absorption of $\mathrm{Pi}$ from the small intestine was regulated, and given the large flux of salivary $\mathrm{P}$ recycling, the effective fractional small intestine absorption of available $\mathrm{P}$ derived from the diet was $41.6 \%$ at requirements. Milk synthesis used $16 \%$ of total absorbed P, and less than $1 \%$ was excreted in urine. The resulting model could be used to derive $\mathrm{P}$ bioavailabilities of commonly used feedstuffs in cattle production.
\end{abstract}

Key words: model, phosphorus, digestion and absorption, dairy cow

Received December 22, 2014.

Accepted May 1, 2015.

${ }^{1}$ Corresponding author: mhanigan@vt.edu

\section{INTRODUCTION}

Eutrophication caused by excessive $\mathrm{P}$ and $\mathrm{N}$ released into aquatic systems impairs growth and survival of aquatic species (Smith et al., 1999). Continuous land application of animal manure based on crop $\mathrm{N}$ demand has resulted in a buildup of $\mathrm{P}$ because the $\mathrm{N}$ to $\mathrm{P}$ ratio in manure typically does not match crop requirements (Ellis and Tillman, 1961). Excessive P often runs off into surface water, aggravating eutrophication. Practices that reduce $\mathrm{P}$ excretion will yield manure that more precisely meets crop needs, thus reducing the risk of P loss. Numerous studies reported that fecal P excretion is positively correlated with dietary $\mathrm{P}$ intake in dairy and beef cattle (Wu et al., 2000; Knowlton and Herbein, 2002; Geisert et al., 2010). Precisely matching dietary $\mathrm{P}$ to animal requirements is essential if excretion is to be minimized. Based on a national survey (Harrison et al., 2012), 99\% of responding nutritionists feed less $\mathrm{P}$ now than they did 5 yr earlier. However, uncertainty regarding feed $\mathrm{P}$ availability is a barrier to further decreases. Current ruminant feeding standards assume homogenous $\mathrm{P}$ absorption from feeds within a few broad feed categories (NRC, 2001). However, previous studies have shown that grain processing (Duskova et al., 2001; Hill et al., 2002), grain type (Bravo et al., 2002; Guyton et al., 2003), and exogenous enzymes (Knowlton et al., 2007) affect P digestion. Improved understanding of $\mathrm{P}$ absorption and recycling is essential to further refine $\mathrm{P}$ feeding recommendations.

Extant $\mathrm{P}$ models considering total $\mathrm{P}$ have focused on interpreting tracer kinetic data on small ruminant $\mathrm{P}$ digestion and metabolism (Vitti et al., 2000; Dias et al., 2006, 2011). In grain-based diets, 65 to $70 \%$ of $\mathrm{P}$ is organically bound in phytate (Morse et al., 1992), which is unavailable for nonruminant animals because they do not express phytase, which catalyzes the release of phosphate from phytate. However, ruminal microbes synthesize phytase, thus making phytate $\mathrm{P}$ at least partially available to ruminants (Liao et al., 2005). The NRC (2001) predicts constant P absorption for forages (64\%) and concentrates (70\%), suggesting that phytate $\mathrm{P}$ from grains is as available as the organic and inorganic $\mathrm{P}$ in forages. Ruminal $\mathrm{P}$ availability is 
greatly influenced by feed type and processing method (Kincaid and Rodehutscord, 2005) as well as P form. Thus, fixed absorption coefficients may misrepresent dietary $\mathrm{P}$ supply.

The model of Hill et al. (2008) fractions P into 3 pools: inorganic $\mathrm{P}(\mathbf{P i})$, phytate $\mathrm{P}(\mathbf{P} \mathbf{p})$, and nonphytate, organic $\mathrm{P}(\mathbf{P o})$. This structure can accommodate differences in digestibility of the different $\mathrm{P}$ forms. As a result, the model can provide an improved understanding of $\mathrm{P}$ digestion and metabolism. The model also simulates degradation of $\mathrm{P}$ in the small $(\mathbf{S I})$ and large intestines (LI) separately, thus accommodating different digestion and absorption mechanisms employed at these sites. When the model was constructed, insufficient data were available to derive all necessary parameters. Since this time, our group has conducted several experiments (X. Feng, J. P. Jarrett, P. P. Ray, L. Karpinski, B. Willing, and K. F. Knowlton, 2011, personal communication; Feng et al., 2013, 2015; Ray et al., 2012, 2013; Jarrett et al., 2014) that should provide the data required for parameterization of the digestive elements. It was hypothesized that sufficient data were available to parameterize the digestion and metabolism coefficients within the model, and the behavior simulated from the resultant model could be used to derive $\mathrm{P}$ bioavailabilities for various feed ingredients. The objective of the current model work was to fully parameterize the Hill et al. (2008) model using data collected from animals that were ruminally, duodenally, and ileally cannulated, thereby providing a better understanding of the digestion and metabolism of $\mathrm{P}$ in growing and lactating cattle.

\section{MATERIALS AND METHODS}

\section{Overview}

The model consisted of a dynamic system of differential equations coded in Advanced Continuous Simulation Language (acslX, ver. 3.0.2.1, Aegis Technologies Group, Huntsville, AL). Briefly, phosphorus was represented in $\mathrm{Pp}, \mathrm{Po}$, and $\mathrm{Pi}$ forms within the digestive tract, with $\mathrm{Pi}$ absorbed into a blood pool and partitioned into bone, milk, soft tissue (if animals are growing), and urine. A detailed description of the model is provided in Hill et al. (2008), and a schematic diagram is presented in Figure 1.

For model development purposes, a reference state was defined as a cow weighing $600 \mathrm{~kg}$, with a blood volume of $120 \mathrm{~kg}$ (20\% of BW including extracellular space body fluid, (Ternouth, 1968), producing $30 \mathrm{~kg}$ of milk/d, consuming $23 \mathrm{~kg}$ of DM/d with $0.33 \% \mathrm{P}(\mathrm{Pp}$ $40 \%$, Po $30.67 \%$, and Pi $29.33 \%$ ), having a ruminal pas- sage rate of $3.15 / \mathrm{d}(13.1 \% / \mathrm{h})$, an apparent affinity constant $0.033 \mathrm{~g} / \mathrm{L}$ for blood $\mathrm{P}$, and blood $\mathrm{P}$ concentration of $0.0557 \mathrm{~g} / \mathrm{L}$. The dietary $\mathrm{P}$ concentration was chosen to just meet but not exceed NRC requirements for that level of production. Incorporation of $\mathrm{Pi}$ into tissue gain was assumed to be $10 \mathrm{~g} / \mathrm{d}$ if BW was less than mature $\mathrm{BW}$, which was set to $500 \mathrm{~kg}$ in the current model.

\section{Model Changes}

Changes were made to the overall model structure to better accommodate the data available for parameter derivation. A flux was added to accommodate intestinal infusions and a soft tissue $\mathrm{P}$ retention flux was added to better represent $\mathrm{P}$ data from growing animals. These changes are described in detail in the following sections. Throughout this description, the abbreviations used followed the pattern adopted by Hill et al. (2008) and are listed in Table 1 . That general form was $Z_{\mathrm{A}, \mathrm{B}}$ where A represented a substrate or pool and B a product. The $Z$ represented $C$ (concentration, g/L), $F$ (flux, g/d), $K$ (mass action rate constant, $/ \mathrm{d}$ ), $\kappa$ (apparent affinity constant, g/L), $R$ (rate constant, g/d), $f$ (fractional rate or proportioning constant, g/g), $x$ (sensitivity exponent, unitless), or $Q$ (mass or quantity, g). The 3 forms of $\mathrm{P}(\mathrm{Pp}, \mathrm{Po}$, and $\mathrm{Pi}$ ) were represented in the rumen (Rum), SI, and LI. Blood (Bld) and bone Pi were also represented. The differential equations which were altered relative to Hill et al. (2008) are as follows.

The Rumen. Degradation of $\mathrm{Pp}$ in the rumen $\left(F_{\text {PpRum,DegRum }}\right)$ was altered to be a mass action function of ruminal $\operatorname{Pp}\left(Q_{\mathrm{PpRum}}\right)$, which was referenced to the initial pool size of $\mathrm{Pp}$ in the rumen $\left(i Q_{\mathrm{PpRum}}\right)$ :

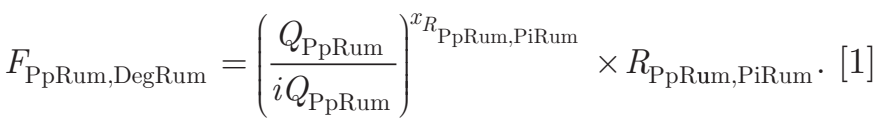

This allowed application of an exponent $\left(x_{R_{\mathrm{P} \text { pRum, }, \mathrm{P} \text { Rum }}}\right)$ to the ratio to adjust sensitivity to changes in the ratio. Although not a functional change, the independent fluxes describing conversion of $\mathrm{Pp}$ to $\mathrm{Po}$ and $\mathrm{Pi}$ were combined into a single overall flux describing the action of phytase, and the fractional production of $\mathrm{Po}$ and $\mathrm{Pi}$ was determined algebraically from the phytase-driven flux.

Phytate, Po, and Pi escape from the rumen, previously represented as a function of a static fluid flow $(198 \mathrm{~L} / \mathrm{d})$, were represented as functions of a specified passage rate $\left(K_{\text {Passage }} ; 3.15 / \mathrm{d}=13.1 \% / \mathrm{h}\right)$ :

$$
F_{\mathrm{PpRum}, \mathrm{PpSI}}=Q_{\mathrm{PpRum}} \times K_{\text {Passage }},
$$




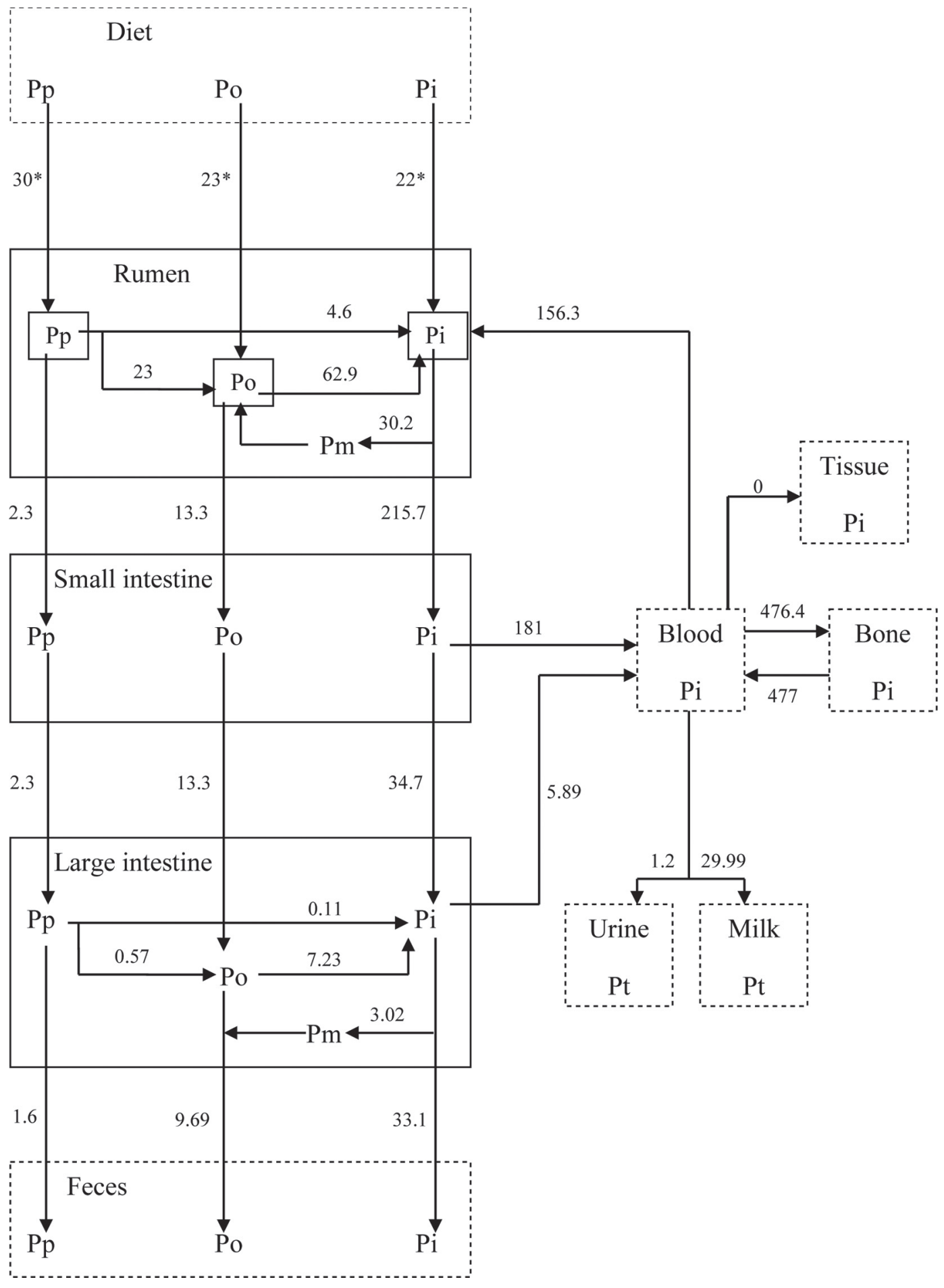

Figure 1. Schematic representation of $\mathrm{P}$ absorption and metabolism in a lactating cow producing $30 \mathrm{~kg}$ of milk/d and consuming $23 \mathrm{~kg} / \mathrm{d}$ of a reference diet formulated to match NRC (2001) P requirements. Boxes with solid lines represent pools, boxes with dashed lines represent compartments, and solid arrows represent fluxes. Numbers associated with arrows denote predicted fluxes for the reference diet using the parameters listed in Table $4 .{ }^{*}$ An asterisk indicates an assumed flux value. $\mathrm{Pt}=$ total $\mathrm{P} ; \mathrm{Pp}=$ phytate $\mathrm{P} ; \mathrm{Po}=$ organic $\mathrm{P}$ excluding phytate; $\mathrm{Pi}$ $=$ inorganic $\mathrm{P} ; \mathrm{Pm}=$ microbial P. 
Table 1. Symbols used in the model

\begin{tabular}{|c|c|}
\hline Symbol & Definition \\
\hline Bld & Blood \\
\hline Bone & Bone \\
\hline$C_{\mathrm{a}}$ & Concentration of $\mathrm{a}, \mathrm{g} / \mathrm{L}$ \\
\hline Deg & Degradation of $\mathrm{P}$ \\
\hline$f$ & Fractional rate or proportioning constant, $\mathrm{g} / \mathrm{g}$ \\
\hline$F_{\mathrm{a}, \mathrm{b}}$ & Flux from pool a to pool $\mathrm{b}, \mathrm{g} / \mathrm{d}$ \\
\hline $\mathrm{Fe}$ & Feces \\
\hline $\mathrm{Fd}$ & Feed \\
\hline$i C_{\mathrm{a}}$ or $i Q_{\mathrm{a}}$ & Initial concentration $(C)$ or mass $(Q)$ of a, $\mathrm{g}$ \\
\hline$\kappa$ & Apparent affinity constant, $\mathrm{g} / \mathrm{L}$ \\
\hline$K_{\mathrm{a}, \mathrm{b}}$ & Mass action rate constant associated with the flux from pool a to pool b, /d \\
\hline $\mathrm{LI}$ & Large intestine \\
\hline Mlk & Milk \\
\hline $\mathrm{Pi}$ & Inorganic $\mathrm{P}$ \\
\hline $\mathrm{Pm}$ & Microbial P \\
\hline Po & Organic P excluding phytate \\
\hline $\mathrm{Pp}$ & Phytate \\
\hline $\mathrm{Pt}$ & Total P \\
\hline$Q_{\mathrm{a}}$ & Quantity or mass of $a, g$ \\
\hline$R$ & Rate constant associated with the flux from pool a to pool b, g/d \\
\hline Rum & 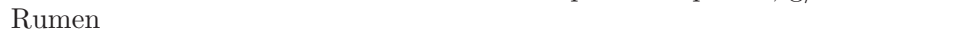 \\
\hline Sal & Saliva \\
\hline SI & Small intestine \\
\hline Urn & Urine \\
\hline
\end{tabular}

$$
\begin{gathered}
F_{\text {PoRum,PoSI }}=Q_{\text {PoRum }} \times K_{\text {Passage }}, \\
F_{\text {PiRum,PiSI }}=Q_{\text {PiRum }} \times K_{\text {Passage }} .
\end{gathered}
$$

[3] The absorption of Pi from the SI was calculated as described in Hill et al. (2008) except that Pi from degradation of $\mathrm{Po}$ in the SI $\left(F_{\text {PoSI,PiSI }}\right)$ and $\mathrm{Pi}$ infused into the omasum $\left(F_{\text {PiOmalInf }}\right)$ were added to accommodate the data of X. Feng, J. P. Jarrett, P. P. Ray, L. Karpinski, B. Willing, and K. F. Knowlton (2011, personal communication).

data suggested that the flow $\mathrm{Pi}$ int rumen due to recycling in saliva $\left(F_{\text {PiBld,PiRum }}\right)$ was more appropriately described by Michaelis-Menten kinetics:

$$
F_{\text {PiBld,PiRum }}=\frac{V_{\text {PiSal }} \times\left(\frac{\text { DMI }}{\text { refDMI }}\right) \times C_{\text {PiBld }}}{\kappa_{\text {PiBld,PiRum }}+C_{\text {PiBld }}},
$$

where $V_{\text {PiSal }}(\mathrm{g} / \mathrm{d})$ and $\kappa_{\text {PiBld,PiRum }}(\mathrm{g} / \mathrm{L})$ represented the maximum velocity for salivary $\mathrm{P}$ secretion and the apparent affinity constant for blood $\mathrm{P}$, respectively.

Phosphorus is required for ruminal microbial growth (MiG), and the $\mathrm{P}$ content of microbes $\left(f_{\mathrm{PiPm}}\right)$ was set to $1.61 \mathrm{~g}$ of P/100 g of microbial DM (Ray et al., 2013) assuming microbial needs were driven solely by growth rates:

$$
F_{\text {PiRum,PmRum }}=\mathrm{MiG} \times f_{\mathrm{PiPm}},
$$

where MiG (g/d) was a specified input to the model.

The Lower Tract. Absorption and flow of $\mathrm{P}$ from the SI was revised to represent potential $\mathrm{Pp}$ degradation in the abomasum after omasal sampling:

$$
F_{\mathrm{PoSI}, \mathrm{PiSI}}=\left(F_{\mathrm{PoRum}, \mathrm{PoSI}}+F_{\mathrm{PpSI}, \mathrm{PoSI}}\right) \times f_{\mathrm{PoSI}, \mathrm{PiSI}} \cdot
$$

$$
\begin{aligned}
F_{\mathrm{PiSI}, \mathrm{PiBld}}= & \left(F_{\mathrm{PiRum}, \mathrm{PiSI}}+F_{\mathrm{PoSI}, \mathrm{PiSI}}+F_{\mathrm{PiOmalInf}}+F_{\mathrm{PpSI}, \mathrm{PiSI}}\right) \\
& \times f_{\mathrm{PiSI}, \mathrm{PiBld}} \times\left(\frac{i Q_{\mathrm{PiBld}}}{Q_{\mathrm{PiBld}}}\right)^{x \mathrm{PiSI}, \mathrm{PiBld}}
\end{aligned}
$$

The exponent $\left(x_{\text {PiSI,PiBld }}\right)$ was included in equation [8] to allow the magnitude of the feedback effect of blood $\mathrm{P}$ on absorption to be derived from observed data, where a value of 0 resulted in no feedback and values greater than 0 in feedback inhibition.

Flow of $\mathrm{Pp}, \mathrm{Po}$, and $\mathrm{Pi}$ to the LI were revised to accommodate $\mathrm{Pp}$ and $\mathrm{Po}$ degradation in the SI:

$$
\begin{gathered}
F_{\mathrm{PpSI}, \mathrm{PpLI}}=F_{\mathrm{PpRum}, \mathrm{PpSI}}-\left(F_{\mathrm{PpRum}, \mathrm{PpSI}} \times f_{\mathrm{PpSI}, \mathrm{DegSI}}\right) \\
F_{\mathrm{PoSI}, \mathrm{PoLI}}=F_{\mathrm{PoRum}, \mathrm{PoSI}}+F_{\mathrm{PpSI}, \mathrm{PoSI}}-F_{\mathrm{PoSI}, \mathrm{PiSI}}, \\
F_{\mathrm{PiSI}, \mathrm{PiLI}}=F_{\mathrm{PiRum}, \mathrm{PiSI}}+F_{\mathrm{PoSI}, \mathrm{PiSI}} \\
+F_{\mathrm{PiOmalInf}}-F_{\mathrm{PiSI}, \mathrm{PiBld}} .
\end{gathered}
$$


Ileal infusion of $\operatorname{Pp}\left(F_{\text {PplleInf }}\right)$ was included in the representation of $\mathrm{Pp}$ degradation in the LI, and a unique degradation constant was applied as infused $\mathrm{Pp}$ and $\mathrm{Pp}$ flowing from the SI were observed to have different degradation:

$F_{\mathrm{PpLI}, \text { DegLI }}=\left(F_{\mathrm{PpSI}, \mathrm{PpLI}} \times f_{\mathrm{PpLI}, \text { DegLI }}\right)+\left(F_{\mathrm{PpIleInf}} \times f_{\mathrm{PpInf}, \text { DegLI }}\right)$.

Fluxes within the LI were assumed to follow the same degradation path for $\mathrm{Pp}$ as described in the rumen, and included the degradation of infused $\mathrm{Pp}$ to $\mathrm{Po}\left(F_{\mathrm{Pp} \text { lleInf }}\right.$; infused $\mathrm{Pp}$ solutions also contained $\mathrm{Po}$ and $\mathrm{Pi})$ :

$$
\begin{gathered}
F_{\mathrm{PpLI}, \mathrm{PiLI}}=F_{\mathrm{PpLI}, \mathrm{DegLI}} \times f_{\mathrm{PpRum}, \mathrm{PiRum}}, \\
F_{\mathrm{PpLI}, \mathrm{PoLI}}=F_{\mathrm{PpLI}, \text { DegLI }} \times\left(1-f_{\mathrm{PpRum}, \mathrm{PiRum}}\right), \\
F_{\mathrm{PoLI}, \mathrm{PiLI}}=\left(F_{\mathrm{PoSI}, \mathrm{PoLI}}+F_{\mathrm{PpLI}, \text { PoLI }}+F_{\text {PolleInf }}\right) \times f_{\mathrm{PoLI}, \mathrm{PiLI}} .
\end{gathered}
$$

Similar to ruminal microbial $\mathrm{P}$ calculations, the flux of Pi to Pm in the LI ( $\left.F_{\text {PiLl,PmLI }}\right)$ was driven by microbial growth $\left(\mathrm{MiG}_{\mathrm{LI}}\right)$ assuming microbial growth in the LI was $10 \%$ of ruminal growth rates. This growth rate was selected to approximate the proportion of total-tract fermentation occurring in the LI (Verbic et al., 1990):

$$
F_{\mathrm{PiLI}, \mathrm{PmLI}}=\mathrm{MiG}_{\mathrm{LI}} \times f_{\mathrm{PiPm}} .
$$

Absorption of Pi from the LI ( $\left.F_{\text {PiLI.PiBld }}\right)$ has been observed (Ray et al., 2013; Feng et al., 2015) and was represented as

$$
\begin{aligned}
F_{\text {PiLI,PiBld }}= & \left(F_{\mathrm{PpLI}, \mathrm{PiLI}}+F_{\mathrm{PoLI}, \mathrm{PiLI}}+F_{\mathrm{PiSI}, \mathrm{PiLI}}\right. \\
& \left.+F_{\mathrm{PiIlleInf}}-F_{\mathrm{PiLI}, \mathrm{PmLI}}\right) \times f_{\mathrm{PiLI}, \mathrm{PiBld}} .
\end{aligned}
$$

Fecal output of $\mathrm{Pp}, \mathrm{Po}$, and Pi were calculated as below with the infused $\mathrm{P}$ from the ileum being added to the equations:

$$
\begin{aligned}
F_{\mathrm{PpLI}, \mathrm{PpFe}}= & F_{\mathrm{PpSI}, \mathrm{PpLI}}+F_{\mathrm{PpIleInf}}-F_{\mathrm{Pp}, \mathrm{Deg} L I}, \\
F_{\mathrm{PoLI}, \mathrm{PoFe}}= & F_{\mathrm{PoSI}, \mathrm{PoLI}}+F_{\mathrm{PpLI}, \mathrm{PoLI}}+F_{\mathrm{PiLI}, \mathrm{PmLI}} \\
& +F_{\mathrm{PoIleInf}}-F_{\mathrm{PoLI}, \mathrm{PiLI}}, \\
F_{\mathrm{PiLI}, \mathrm{PiFe}}= & F_{\mathrm{PiSI}, \mathrm{PiLI}}+F_{\mathrm{PoLI}, \mathrm{PiLI}}+F_{\mathrm{PpLI}, \mathrm{PiLI}} \\
& +F_{\mathrm{Pi} i l e I n f}-F_{\mathrm{PiLI}, \mathrm{PmLI}}-F_{\mathrm{PiLI}, \mathrm{PiBld}} .
\end{aligned}
$$

Blood Phosphorus. The flux of $\mathrm{Pi}$ absorbed from the LI ( $\left.F_{\text {PiLI,PiBld }}\right)$ was added to the differential equation for $\mathrm{Pi}$ in blood:

$$
\begin{aligned}
\frac{\mathrm{d} Q_{\text {PiBld }}}{\mathrm{d} t}= & F_{\text {PiBone,PiBld }}+F_{\text {PiSI,PiBld }}+F_{\text {PiLI,PiBld }}-F_{\text {PiBld,PiBone }} \\
& -F_{\text {PiBld,PiMlk }}-F_{\text {PiBld,PiRum }}-F_{\text {PiBld,PiUnn }} .
\end{aligned}
$$

A body-size scalar was added to the equation representing removal of Pi from blood to urine, thus accommodating animals of varying body size:

$$
F_{\text {PpRum,DegRum }}=\left(\frac{Q_{\text {PiBld }}}{i Q_{\text {PiBld }}}\right)^{x_{\text {PiBld }}} \times R_{\text {PiBld,PiUrn }} \times \frac{\text { BW }}{\text { refBW }} .
$$

Bone Phosphorus. A new flux representing $\mathrm{P}$ use for growth $\left(F_{\text {PiGain }}\right)$ was added to the differential equation for bone $\mathrm{P}$ to reflect the $\mathrm{P}$ retention rate in gain (g/d) in young animals. If BW was less than mature BW (set as $500 \mathrm{~kg}$ in this model), $F_{\text {PiGain was equal to }}$ $R_{\text {PiGain }}$, otherwise $F_{\text {PiGain }}$ was 0 .

$$
\frac{\mathrm{d} Q_{\text {PiBone }}}{\mathrm{d} t}=F_{\text {PiBld,PiBone }}+F_{\text {PiGain }}-F_{\text {PiBone,PiBld }} .
$$

A scalar for body size was included in calculating the flux of Pi between blood and bone:

$$
\begin{gathered}
F_{\mathrm{PiBld}, \mathrm{PiB} o n e}=Q_{\mathrm{PiBld}} \times K_{\mathrm{PiBld}, \mathrm{PiBone}} \times \frac{\mathrm{BW}}{\mathrm{refBW}}, \\
F_{\mathrm{PiBone}, \mathrm{PiBld}}=Q_{\mathrm{PiBone}} \times K_{\mathrm{PiBone}, \mathrm{PiBld}} \times \frac{\mathrm{BW}}{\mathrm{refBW}} .
\end{gathered}
$$

Total $\mathrm{P}$ balance in the body was represented as the difference between total input and output thereby allowing comparison with $\mathrm{P}$ balance calculated for animal observations:

$$
\begin{aligned}
\text { Balance }_{\mathrm{Pt}}= & F_{\mathrm{PtFd}, \mathrm{PtRum}}+F_{\mathrm{PiOmalInf}}+F_{\mathrm{PpIleInf}}+F_{\mathrm{PoIleInf}} \\
& +F_{\mathrm{PilleInf}}-F_{\mathrm{PtLI}, \mathrm{PtFe}}-F_{\mathrm{PiBld}, \mathrm{PiUrn}}-F_{\mathrm{PiBld}, \mathrm{PiMlk}} .
\end{aligned}
$$

\section{Experimental Data Description}

The model was fitted to data from 6 experiments from our laboratory, which will be denoted using the author's initials: LK1 (X. Feng, J. P. Jarrett, P. P. Ray, L. Karpinski, B. Willing, and K. F. Knowlton, 2011, 
Table 2. Mean of observed data for Ray et al. (2012, 2013), Feng et al. (2011, personal communication), Feng et al. (2013, 2015), and Jarrett et al. (2014)

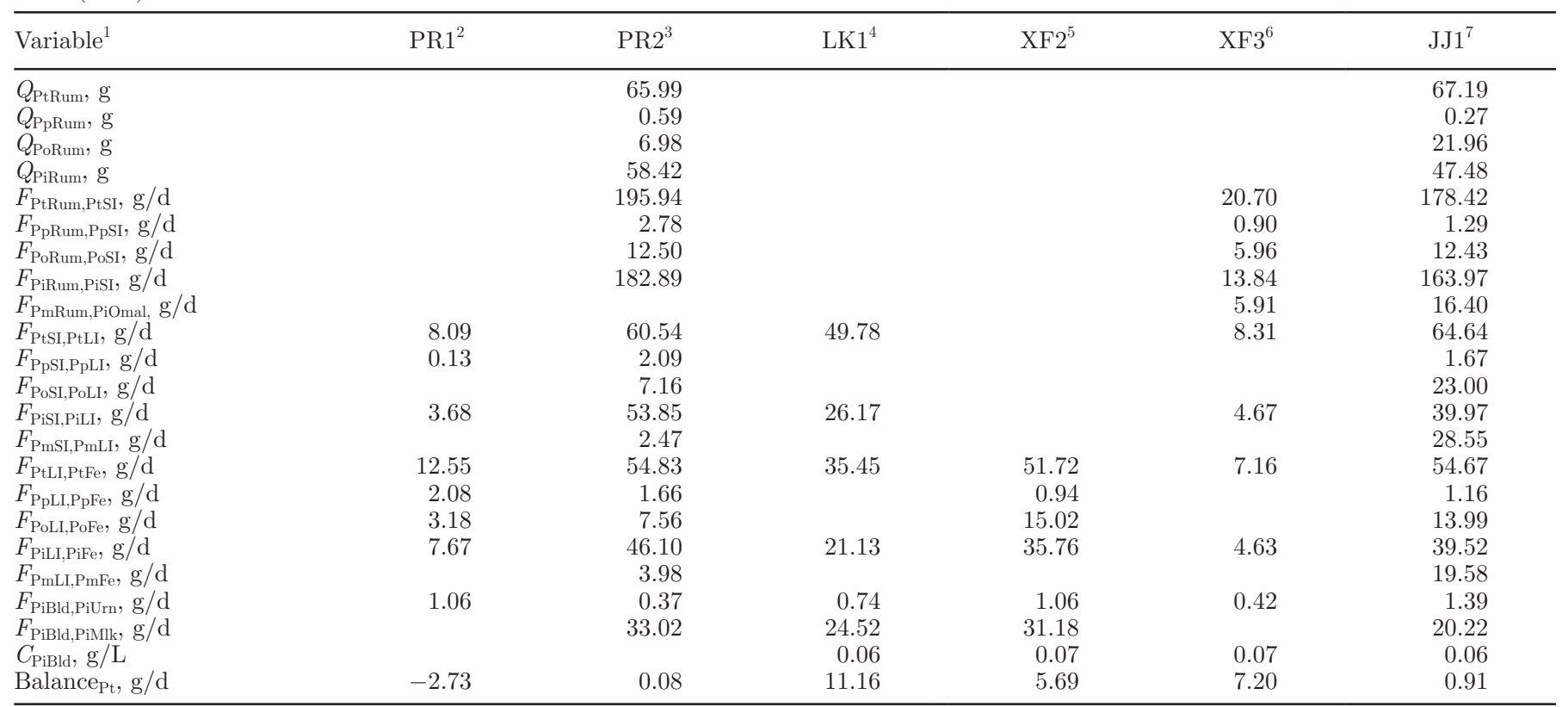

${ }^{1}$ Variable abbreviations as given in Table 1 .

${ }^{2}$ Ray et al. (2012).

${ }^{3}$ Ray et al. (2013).

${ }^{4}$ Feng et al. (2011, personal communication): X. Feng, J. P. Jarrett, P. P. Ray, L. Karpinski, B. Willing, and K. F. Knowlton.

${ }^{5}$ Feng et al. (2013).

${ }^{6}$ Feng et al. (2015).

${ }^{7}$ Jarrett et al. (2014).

personal communication), XF2 (Feng et al., 2013), XF3 (Feng et al., 2015), PR1 (Ray et al., 2012), PR2 (Ray et al., 2013), and JJ1 (Jarrett et al., 2014). The data are summarized in Table 2. Inputs to the model were DMI; proportion of total $\mathrm{P}$ in feed $\left(f_{\mathrm{PtFd}}\right)$; $\mathrm{Pp}$, $\mathrm{Po}$, and $\mathrm{Pi}$ as proportions of total $\mathrm{P}\left(f_{\mathrm{PpPt}}, f_{\mathrm{PoPt}}, f_{\mathrm{PiPt}}\right)$; ruminal microbial growth $(\mathrm{MiG})$; amount of $\mathrm{Pi}, \mathrm{Po}$, and $\mathrm{Pp}$ infused into the omasum or ileum; milk yield; and $\mathrm{BW}$ (Table 3). Milk yield, BW, total $\mathrm{P}$ intake, and proportion of $\mathrm{Pp}$ and $\mathrm{Pi}$ in feed were measured. Organic $\mathrm{P}$ was obtained by subtracting $\mathrm{Pp}$ and $\mathrm{Pi}$ from total P. Ruminal microbial growth was calculated using the equation from Firkins et al. (1998).

Except for the LK1 study (data in Appendix Table A1), the procedures used to collect the data and the experimental treatments were described in the primary paper. In the LK1 study, 4 ruminally and ileally cannulated crossbred cows were used in a $4 \times 4$ Latin square with 21-d periods. Cows were fed a TMR containing $0.21 \% \mathrm{P}$, providing $50 \%$ of their estimated $\mathrm{P}$ requirement. On d 13 to 21 of each period, each cow was abomasally infused with $0,20.1,40.2$, or $60.3 \mathrm{~g} / \mathrm{d}$ of Pi. Ileal samples were collected every $9 \mathrm{~h}$ and total fecal collection was conducted from d 18 to 21 . Blood samples were obtained on d 20 and 21 of each period from the coccygeal vessel.

\section{Parameter Estimation and Model Evaluation}

Parameter estimates were derived from the above data using aclsX and a least squares optimization algorithm (NL2SOL; Powell, 1970) that used an approximation of the Hessian matrix to search the parameter space based on gradient information. Parameters fitted included those describing $\mathrm{P}$ degradation and metabolism in the rumen $\left(R_{\text {PpRum,PiRum, }} K_{\text {PoRum,PiRum, }} V_{\text {PiSal }}\right)$, small intestine $\left(f_{\mathrm{PiSI}, \mathrm{PiBld}}\right)$, large intestine $\left(f_{\mathrm{PpLI}, \mathrm{DegLI}}\right.$, $\left.f_{\text {PoLIIPiLI }}, f_{\text {PiLIIPiBld }}\right)$, growth $\left(R_{\text {PiGain }}\right)$, and $\mathrm{P}$ flow from blood to bone and urine $\left(K_{\mathrm{PiBld}, \mathrm{PiB} \text { ene }}, R_{\mathrm{PiBld}, \mathrm{PiUrn}}\right)$. Initial fits included parameter estimates for $\mathrm{Pp}$ and $\mathrm{Po}$ degradation in the SI $\left(f_{\mathrm{PpSI}, \text { DegSI }}, \mathrm{f}_{\mathrm{PoSI} \text {.DegSI }}\right)$, but these were found to be essentially 0 and thus were fixed to values of 0 and removed from the parameter estimation list. The exponents controlling Pp degradation in the rumen (equation [1]) and $\mathrm{Pi}$ absorption from the SI (equation [8]) were not uniquely identifiable from the data, but range testing indicated they should be set to values of approximately 2.0 and 2.5 , respectively, and 
Table 3. Model inputs for Ray et al. (2012, 2013), Feng et al. (2011, personal communication), Feng et al. (2013, 2015), and Jarrett et al. (2014)

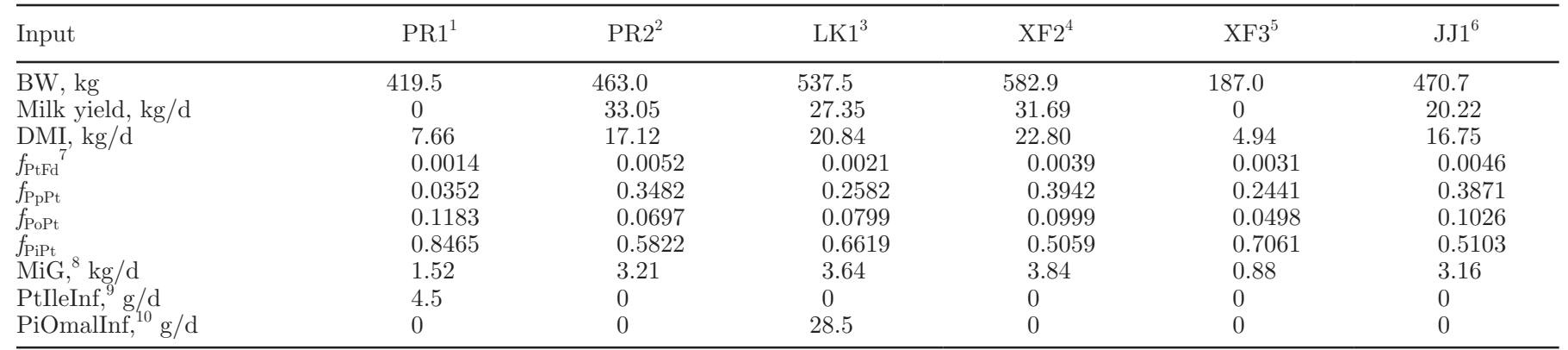

${ }^{1}$ Ray et al. (2012).

${ }^{2}$ Ray et al. (2013).

${ }^{3}$ Feng et al. (2011, personal communication): X. Feng, J. P. Jarrett, P. P. Ray, L. Karpinski, B. Willing, and K. F. Knowlton.

${ }^{4}$ Feng et al. (2013).

${ }^{5}$ Feng et al. (2015).

${ }^{6}$ Jarrett et al. (2014).

${ }^{7} f_{\mathrm{ab}}$, fractional proportion of a in b [e.g., $f_{\mathrm{PtFd}}$ is proportion of $\mathrm{Pt}$ (total P) in Fd (feed)]. This also applies to $f_{\mathrm{PpPt}}, f_{\mathrm{PoPt}}$, and $f_{\mathrm{PiPt}}$. Po $=$ organic $\mathrm{P} ; \mathrm{Pp}=$ phytate $\mathrm{P} ; \mathrm{Pi}=$ inorganic $\mathrm{P}$.

${ }^{8}$ Microbial growth.

${ }^{9}$ Total amount of $\mathrm{P}$ infused in the ileum, including Pi, Pp, and Po.

${ }^{10}$ Total amount of Pi infused in the omasum.

thus these values were adopted for the final parameter estimations and all subsequent work. Therefore, a total of 10 parameters were fitted to the data (Table 4).

Standard deviations of the estimates were derived using a bootstrap approach (Efron, 2012) assuming that residual errors reflected variance in the observed data. Residual errors were randomly sampled, and each sample was applied to a random observed value of each variable. This resampling was repeated once for each available observation. When the complete set of observations was resampled, the parameters were optimized again. This procedure was repeated 700 times and the resulting population of parameter estimates was used to determine the standard deviation of estimates.

Overall variance of the predictions was determined by calculation of the mean square prediction error (MSPE) as described by Biddy and Toutenberg (1977):

$$
\operatorname{MSPE}=\frac{1}{n} \sum_{i=1}^{n}\left(O_{i}-P_{i}\right)^{2},
$$

where $n$ represents the total number of observations, $O_{i}$ the observed value, and $P_{i}$ the predicted value. It was decomposed into error due to random variation, deviation of the regression slope from unity (slope bias), and central bias (mean bias). Root mean square prediction errors (RMSPE) were obtained by taking the square root of the MSPE. It was expressed as a proportion of the observed mean as an estimate of the overall prediction error.

Global sensitivity analyses were conducted as previously described (Saltelli et al., 1999) to determine the sensitivity of $\mathrm{P}$ fluxes in different compartments to total $\mathrm{P}$ intake; proportions of $\mathrm{Pp}, \mathrm{Po}$, and $\mathrm{Pi}$ in the diet; and the 10 parameter estimates. An interference

Table 4. Model parameter estimates and standard deviations derived from fitting to the data listed in Table 2

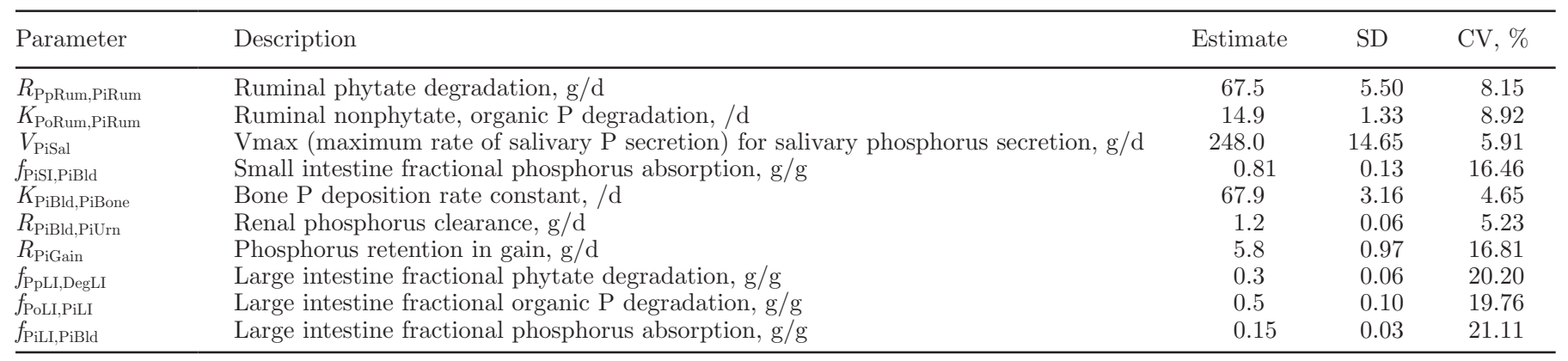


factor of 4 and 4 resamplings was used. Analyses were performed using the FAST algorithm with the default frequency step. The minimum and maximum range of $\mathrm{P}$ intake and proportions of dietary $\mathrm{Pp}, \mathrm{Po}$, and $\mathrm{Pi}$ were set equal to the range of the observed data. The minimum and maximum range of the 10 parameter estimates were set to 80 and $120 \%$ of the parameter estimates, respectively.

\section{RESULTS AND DISCUSSION}

The standard deviation of parameter estimates derived from fitting the model to the observed data were low $(<21 \%$ of the parameter estimate), indicating the data were adequate to define the model with a high degree of confidence. Root mean squared prediction errors ranged from $22.6 \%$ of the observed mean for ruminal Pt pool size up to $265 \%$ for $\mathrm{P}$ balance. However, in the latter case, the observed mean was $3.16 \mathrm{~g} / \mathrm{d}$ with an RMSPE of $8.15 \mathrm{~g} / \mathrm{d}$ compared with a mean Pt intake of $54 \mathrm{~g} / \mathrm{d}$. Thus, the error was not particularly large in magnitude even though it was proportionally so. Of the fluxes, the largest absolute error was for Pt flow from the rumen at $38.7 \mathrm{~g} / \mathrm{d}$. However, that flow was also the largest flux averaging $119 \mathrm{~g} / \mathrm{d}$. When prediction errors were expressed as a proportion of total $\mathrm{P}$ intake, most were less than $15 \%$ of $\mathrm{P}$ intake. Blood concentrations were predicted with a $24 \%$ error with approximately $35 \%$ of that error almost evenly split between mean and slope bias. Given the errors inherent in making many of the measurements (20\% or greater), the RMSPE values indicate relatively good agreement with the observed biology. The lack of significant mean or slope bias in the predictions also supports this assertion (Table 5 and Figures 2 and 3).

\section{The Rumen}

The revised model was compared with the original model by setting model inputs to the reference input values used in the prior work. Given intakes of 30, 23, and $22 \mathrm{~g} / \mathrm{d}$ of $\mathrm{Pp}, \mathrm{Po}$, and $\mathrm{Pi}$, the model predicted 2.3, 13.3 , and $215.7 \mathrm{~g} / \mathrm{d}$ of $\mathrm{Pp}, \mathrm{Po}$, and Pi flow to the SI, respectively (Figure 1). More $\mathrm{Pp}$ was degraded in the rumen in the revised model than the original model (27.7 vs. $23 \mathrm{~g} / \mathrm{d}$, respectively). Approximately $63 \mathrm{~g} / \mathrm{d}$ of Po was converted to $\mathrm{Pi}$ in the revised model, whereas no ruminal Po degradation was assumed in the original model. Predicted microbial P outflow was also higher compared with the original model (30 vs. $14 \mathrm{~g} / \mathrm{d}$ ) and was higher than the expected synthesis rate of $12 \mathrm{~g} / \mathrm{d}$ based on average microbial $\mathrm{P}$ content (Durand and Kawashima, 1980).

Digestibility of $\mathrm{Pp}$ in the rumen was $92 \%$, which was much greater than that for the original model $(74 \%)$. Phytase sequentially hydrolyzes phytate (inositol phosphate with 6 phosphate molecules; IP6) to lower inositol phosphates (IP5, IP4, IP3, and IP2) plus phosphoric acid and eventually inositol (Anderson, 1915). Park et al. (2002) suggested the rate of production of IP3 from highly phosphorylated IP (IP6, IP5, and IP4) exceeded the rate of degradation of IP3 in the forestomach indicating that ruminal phytase preferentially degrades highly phosphorylated inositols. The model represented

Table 5. Model prediction errors associated with prediction of the data of 6 studies

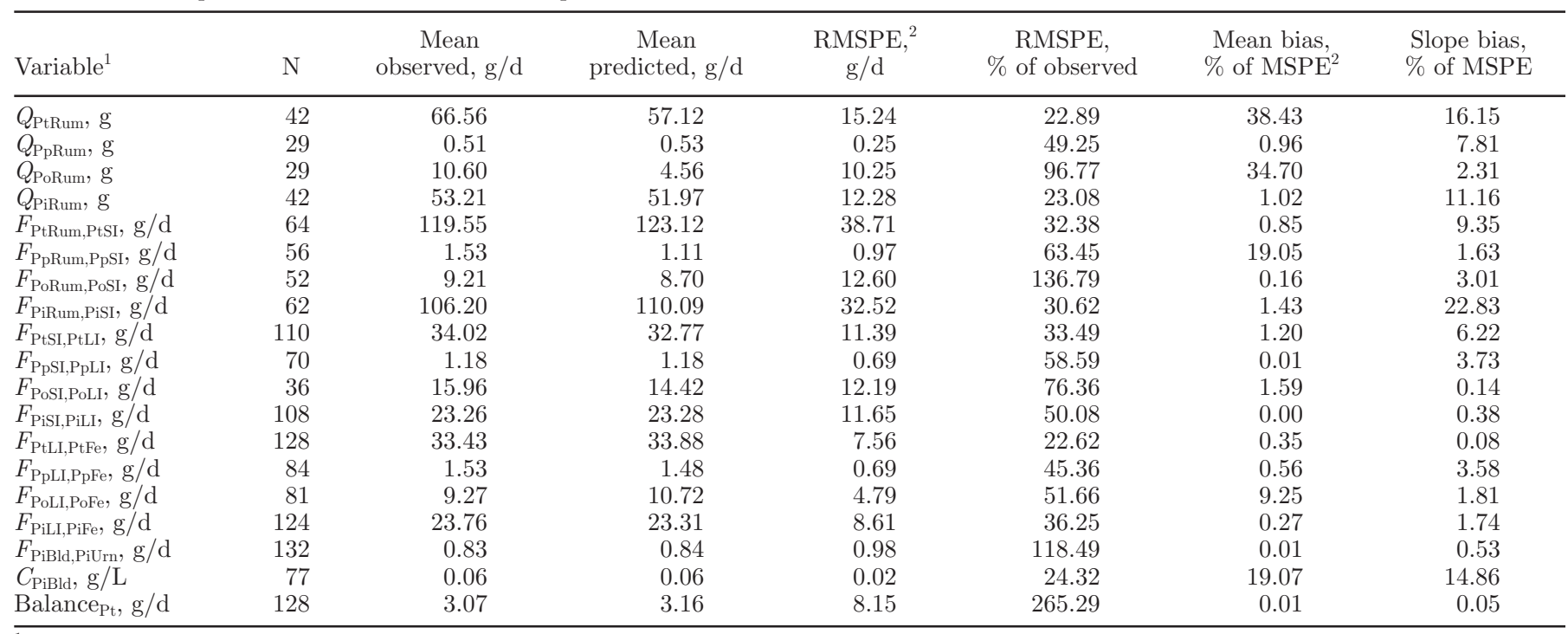

${ }^{1}$ Variable abbreviations as given in Table 1.

${ }^{2} \mathrm{RMSPE}=$ root mean square prediction errors; MSPE $=$ mean square prediction error. 


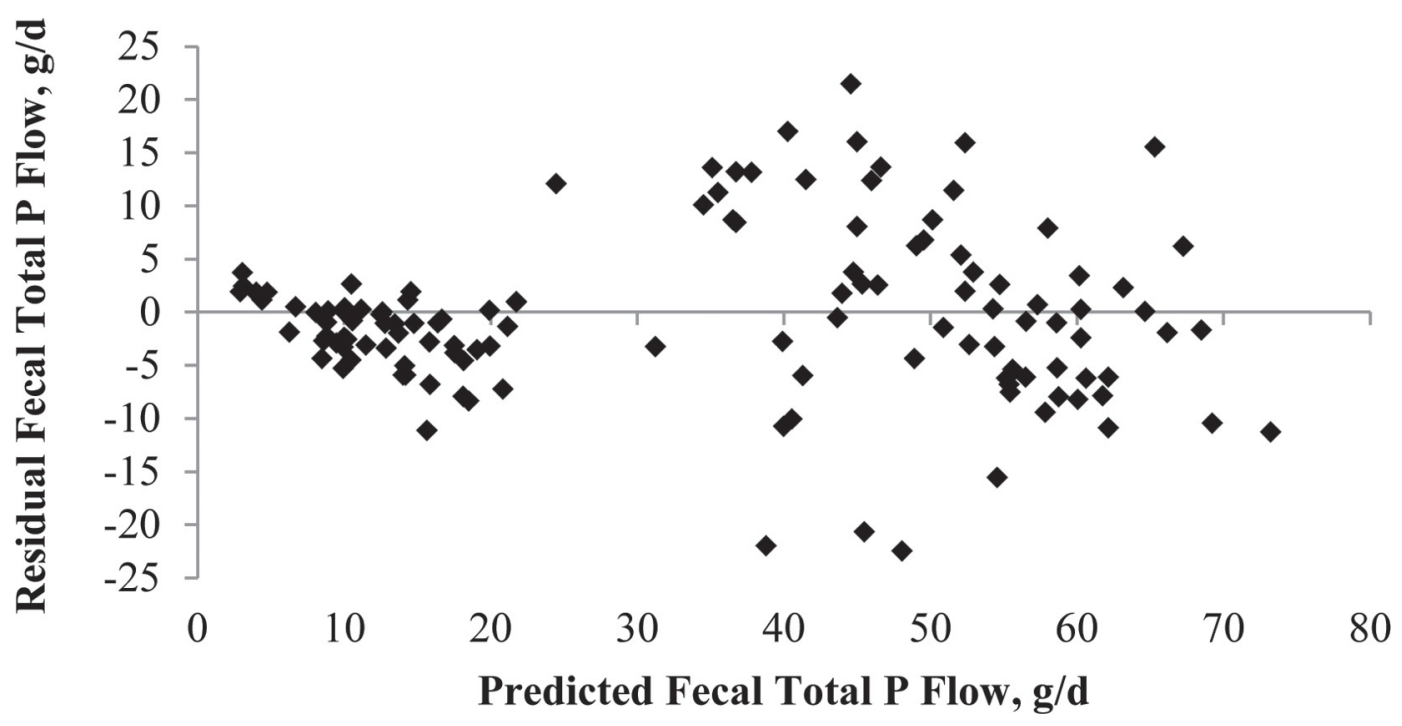

Figure 2. Residual errors for predictions of total fecal P flow versus predicted flow. Simulations are of the data summarized in Table 3 using inputs outlined in Table 2 and the model parameters listed in Table 4.

the lower order IP (IP5 through IP2) in aggregate within the Po pool; thus, conclusions regarding differential rates of degradation of the various IP are restricted to IP6 $(\mathrm{Pp})$ versus lower IP plus other organic forms $(\mathrm{Po})$. The rate constant for degradation of IP6 $\left(R_{\text {PpRum,PiRum }}\right)$ was $67.5 \mathrm{~g} / \mathrm{d}$, whereas the rate of degradation of Po ( $K_{\mathrm{PoRum}, \mathrm{PiRum}}$ ) was $14.9 / \mathrm{d}$. The reduced rate of Po degradation versus $\mathrm{Pp}$ degradation is consistent with the observations of Park et al. (2002) and suggests the ratelimiting step in phytate degradation is not cleavage of the first $\mathrm{Pi}$. This is also consistent with the relatively larger Po pool in the rumen as compared with the $\mathrm{Pp}$ pool. For the reference status cow, the turnover rate of the Pp pool is $158.8 \% / \mathrm{h}$, whereas the turnover rate of the $\mathrm{Po}$ pool is $61.9 \% / \mathrm{h}$, given pool sizes for $\mathrm{Pp}$ and $\mathrm{Po}$ of 0.72 and $4.23 \mathrm{~g}$, respectively.

The total P flow to the SI was almost 3-fold the total dietary $\mathrm{P}$ input to the rumen due to a large salivary P flux as noted previously by Ray et al. (2013) and Jarrett et al. (2014). Because not all of the secreted P is reabsorbed in the SI, this flux serves as the major route of disposal. It also may have evolved to ensure

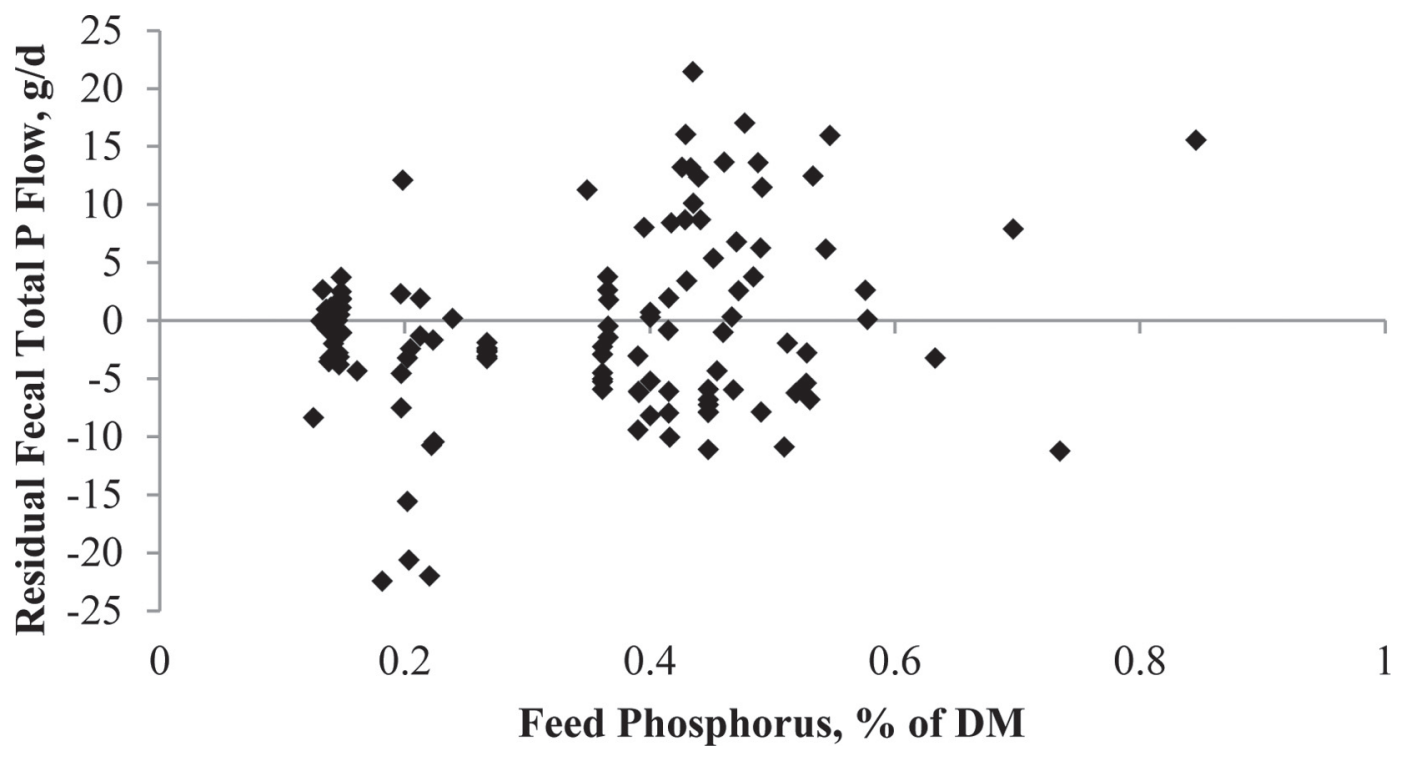

Figure 3. Residual errors for predictions of total fecal P flow versus the concentration of $\mathrm{P}$ in feed. Simulations are of the data summarized in Table 3 using inputs outlined in Table 2 and the model parameters listed in Table 4. 
adequate Pi availability for the microbes in the rumen (Puggaard et al., 2011).

\section{SI and LI}

In the revised model the parameter estimates for $\mathrm{Pp}$ and Po degradation in the SI $\left(f_{\mathrm{PpSI}, \mathrm{DegSI}}, f_{\mathrm{PoSI}, \mathrm{DegSI}}\right)$ solved for values that were not significantly different from 0 in initial runs, and thus were fixed to 0 for subsequent fits to the data. It was not surprising that $\mathrm{Pp}$ degradation was 0 , although the possibility of apparent degradation in the SI for omasally sampled animals existed due to the fact that phytase is most active at low $\mathrm{pH}$ in the abomasum after the omasal sample has been taken. The absence of any apparent degradation may reflect the extensive degradation in the rumen. Given the extremely high rate of degradation of $\mathrm{Pp}$ in the rumen, failure to go to completion may be a reflection of the presence of some resistant material. This would explain the apparent lack of phytase activity in the SI even in animals that were omasally sampled.

Approximately $83 \%$ of $\mathrm{Po}$ appearing in the rumen from feed, $\mathrm{Pp}$ degradation, and $\mathrm{Pm}$ synthesis was converted to $\mathrm{Pi}$ in the rumen, and $42.8 \%$ of the $15.9 \mathrm{~g} / \mathrm{d}$ appearing in the LI was converted to Pi. Surprisingly Po digestion in the SI was negligible. The $\mathrm{P}$ present in plant and microbial phospholipids and nucleic acids should have been represented in the Po pool given the method of conducting the fractionation. Both molecules are known to be absorbed from the intestine (Blomstrand, 1955; Verbic et al., 1990) and thus one would expect some absorption across the SI. The lack of such an event may be due to inadequate enzymatic activity, or possibly Po remaining after the extensive degradation in the rumen was resistant to enzymatic attack. Another possibility is secretion of Po (i.e., phospholipids from sloughed cells) into the intestine and the absorption of Po flowing from the rumen is offset by secretion of Po into the gut lumen.

Absorption of $\mathrm{Pi}$ from the SI averaged $84 \%$ of that flowing from the rumen, which equates to $181 \mathrm{~g} / \mathrm{d}$ for the reference diet (Figure 1). This is approximately 3 times Pt intake. However, due to the negative feedback effects of blood $\mathrm{Pi}$ on the rate of SI absorption (equation [8]), fractional extraction would be greater for low$\mathrm{P}$ diets and less for high-P diets. Flow of $\mathrm{P}$ to the $\mathrm{SI}$ is dominated by $\mathrm{P}$ re-entry into the rumen as observed by Ray et al. (2013). Of the $181 \mathrm{~g} / \mathrm{d}$ absorbed in the reference state, $156 \mathrm{~g} / \mathrm{d}$ are secreted back into the rumen. If one applies the fractional absorption rate of $84 \%$ to the recycled flux, $131 \mathrm{~g}$ of the secreted $156 \mathrm{~g}$ would be absorbed from the SI and the remaining $25 \mathrm{~g}$ would flow to the LI and to feces. This recycling to the rumen is an efficient method of helping to regulate $\mathrm{P}$ supply to the animal. It allows high-P absorption to ensure adequate supply and excretion of the excess back into the rumen to help prevent ruminal $\mathrm{P}$ deficiency. From an application standpoint, the apparent absorption is greatly reduced due to this large recycling flux. The flow of nonrecycled, feed-derived Pi from the rumen on the reference diet is $59.4 \mathrm{~g} / \mathrm{d}$ and total $\mathrm{Pi}$ flow at the ileum is $34.7 \mathrm{~g} / \mathrm{d}$, yielding an apparent Pi digestibility of $41.6 \%$ in the SI, which is the effective absorption coefficient for the SI. Reduced dietary inputs would reduce the rate of absorption based on mass action causing reduced ruminal recycling and thus an increase in the effective SI absorption coefficient, and the reverse for increased dietary inputs. Because the reference diet generates a $\mathrm{P}$ balance of very close to 0 , the effective absorption rate is that which one would expect at the $\mathrm{P}$ requirement and thus can be used to generate bioavailability values for lactating cows.

Of the $2.3 \mathrm{~g} / \mathrm{d}$ of $\mathrm{Pp}$ entering the LI, $0.7 \mathrm{~g} / \mathrm{d}$ was degraded. Ray et al. (2013) observed an average of 0.4 $\mathrm{g} / \mathrm{d}$ of $\mathrm{Pp}$ degradation in the LI as a result of microbial activity. Contrary to the lack of Po degradation in the SI, more than $50 \%$ of Po entering the LI was degraded to $\mathrm{Pi}$. The combination of $\mathrm{Pi}$ flow from the SI and $\mathrm{Pp}$ and $\mathrm{Po}$ degradation in the LI, results in a fairly substantial supply of $\mathrm{Pi}$ ( $42 \mathrm{~g} / \mathrm{d}$ on the reference diet). Although a portion of the available $\mathrm{Pi}$ is assumed to be used by intestinal microbes $(3 \mathrm{~g} / \mathrm{d})$ and $6 \mathrm{~g} / \mathrm{d}$ is absorbed, $78 \%$ of it is excreted in feces. Absorption of Pi from the LI is a relatively new concept (Ray et al., $2013)$; its contribution to the overall animal supply is minor compared with SI absorption, which agrees with the prior body of work (NRC, 2001).

One of the objectives of the overall $\mathrm{P}$ project in our laboratory (experimental plus modeling) was to determine whether different $\mathrm{P}$ fractions had different digestibilities. The apparent total-tract digestibilities of Pp, Po, and Pi based on dietary inputs were 95, 58, and $-150 \%$, respectively. The latter is a function of conversion of $\mathrm{Pp}$ and Po to Pi exceeding Pi absorption from the digestive tract. Clearly, unlike monogastrics, Pp degradation is quite extensive in the digestive tract and seems to offer little opportunity for improvement on average. However, the data used to define the model do not represent the full realm of diets and dietary management, and thus one cannot rule out the possibility that the extent of $\mathrm{Pp}$ degradation is considerably less under some conditions. Because $\mathrm{Po}$ and $\mathrm{Pi}$ arise within the system as a result of $\mathrm{Pp}$ and Po degradation, it is more informative to look at apparent intestinal digestibilities, which are 27 and $85 \%$, respectively, for $\mathrm{Po}$ and $\mathrm{Pi}$. Thus, differences are clearly present in digestibilities of the different fractions with apparent Po digestion being no more than $50 \%$ of supply, whereas 
Pp digestion is extensive, and apparently not of great concern under the conditions of the studies used for parameterization. Finally, apparent Pi absorption is quite extensive; however, the apparent absorption is much less due to a large recycling flux into the rumen, and SI absorption is regulated to resist deficiencies and excess (Figure 4 slope is 16.7\%). The apparent total-tract digestibility of $\mathrm{Pt}$ was predicted to be $40.8 \%$, which is in the range reported by Knowlton and Herbein (2002). One could use the fractional digestibility coefficients for $\mathrm{Pp}$ and $\mathrm{Po}$ and the effective absorption rate for $\mathrm{Pi}$ at neutral $\mathrm{P}$ balance to estimate $\mathrm{P}$ bioavailability for any ingredient provided knowledge of the proportions of $\mathrm{Pp}, \mathrm{Po}$, and $\mathrm{Pi}$ in the ingredient and the assumption that those digestibilities were constant across ingredients. These calculated bioavailabilities could be used directly in the current NRC to better reflect the true supply of $\mathrm{P}$ to the animal.

\section{Blood and Bone Phosphorus}

Of the $187 \mathrm{~g}$ of Pi absorbed from the SI and LI, 156 $\mathrm{g}$ was recycled back to the rumen via saliva, $1 \mathrm{~g} / \mathrm{d}$ was excreted in urine, and $30 \mathrm{~g} / \mathrm{d}$ was secreted in milk for the reference diet and animal (Figure 1). Recycled $\mathrm{P}$ represented $67.5 \%$ of the total $\mathrm{P}$ input to the rumen and was higher than the $45 \%$ recycling reported by Kebreab et al. (2005). As was observed from many studies, urinary $\mathrm{Pi}$ excretion represented a very small proportion of total $\mathrm{P}$ excretion in dairy cattle (Puggaard et al., 2011; Ray et al., 2013; Jarrett et al., 2014). Milk contained about $1 \mathrm{~g}$ of $\mathrm{P}$ per $\mathrm{kg}$ of milk, which was the same as reported by Feng et al. (2013).

Total P balance, calculated as the difference between total $\mathrm{P}$ inputs (diet, infused) and total $\mathrm{P}$ excreted in feces, urine, and milk was predicted to be $-0.59 \mathrm{~g} / \mathrm{d}$ for the reference diet with dietary $\mathrm{P}$ at NRC requirements of $0.33 \%$ of DM (Figure 1). This balance is lower than reported in Puggaard et al. (2011), but that study used a dietary $\mathrm{P}$ concentration of $0.45 \%$. The error of prediction for P balance was observed to be $8.15 \mathrm{~g} / \mathrm{d}$ (Table 5 ), and thus the predicted balance for the reference diet was clearly not significantly different from 0 , indicating the diet was indeed balanced to $\mathrm{P}$ requirements as predicted by the NRC (2001) model.

Total $\mathrm{P}$ balance reflects bone $\mathrm{P}$ balance in the model given no representation of other storage sites. Balance is achievable at $50 \mathrm{~kg}$ of milk/d with a dietary $\mathrm{P}$ content of $0.45 \%$ and DMI of $23 \mathrm{~kg} / \mathrm{d}$, and is fairly resistant to change decreasing approximately $0.17 \mathrm{~g} / \mathrm{d}$ per $\mathrm{kg}$ of milk yield increase with everything else held constant (Figure 4). Reducing dietary P concentration from 0.4 to $0.3 \%$, a $23 \mathrm{~g} / \mathrm{d}$ decrease in $\mathrm{Pt}$ supply, resulted in only a $2.7 \mathrm{~g} / \mathrm{d}$ reduction in $\mathrm{P}$ balance (Figure 5 ). This underscores the extent of the regulation of $\mathrm{Pi}$ uptake in equation [8] and the effect of reduced secretion into

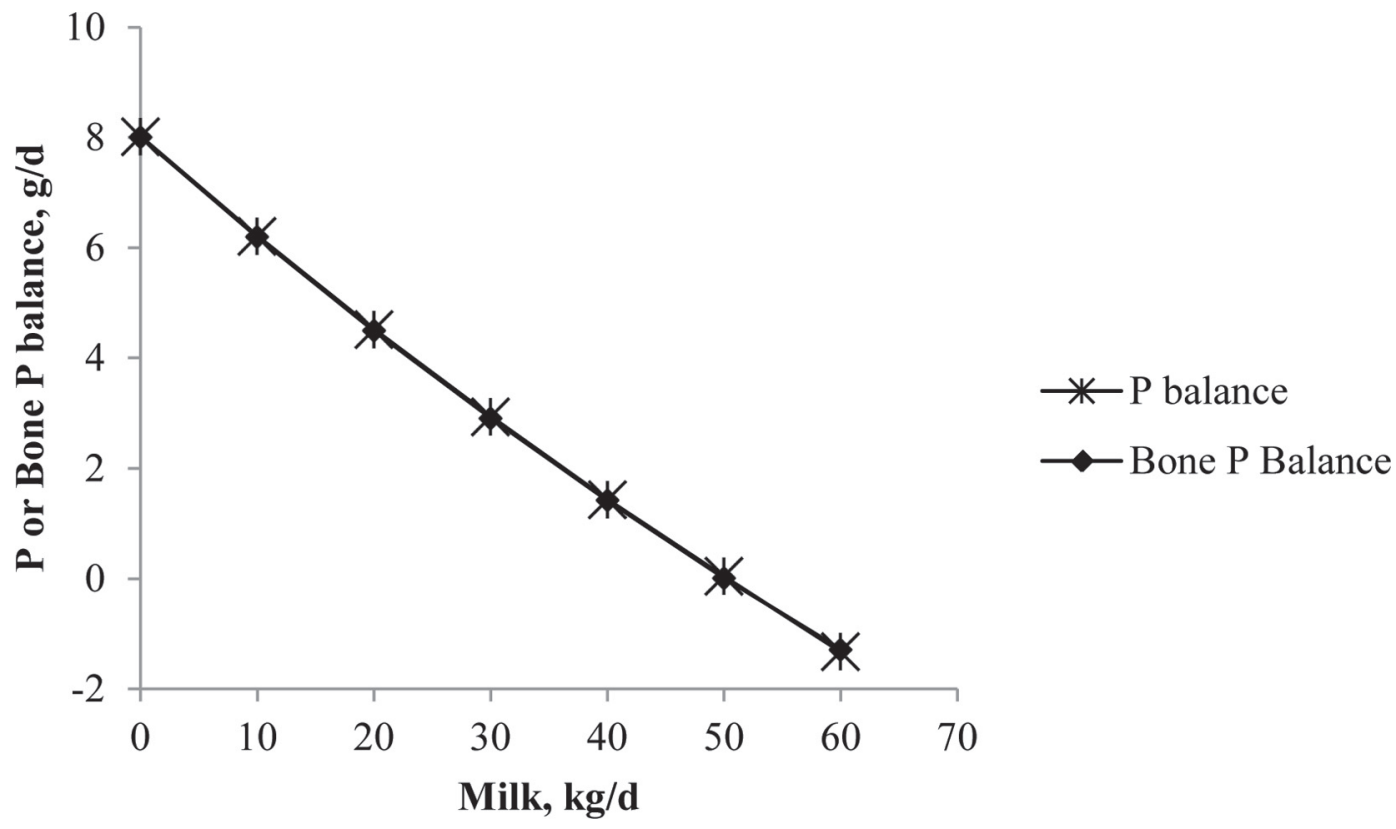

Figure 4. Phosphorus and bone $\mathrm{P}$ balance in response to varied milk yield as predicted by the model using the parameters in Table 4 . The dietary $\mathrm{P}(0.45 \%$ of $\mathrm{DM})$ and proportions of phytate $\mathrm{P}$, and organic and inorganic $\mathrm{P}(33.2,22.3$, and $44.5 \%$, respectively) were held constant as milk yield varied. Dry matter intake was set to $23 \mathrm{~kg} / \mathrm{d}$. Slopes for P balance and bone P balance are -0.1552 and $-0.1548 \mathrm{~g} / \mathrm{kg}$ of milk. 


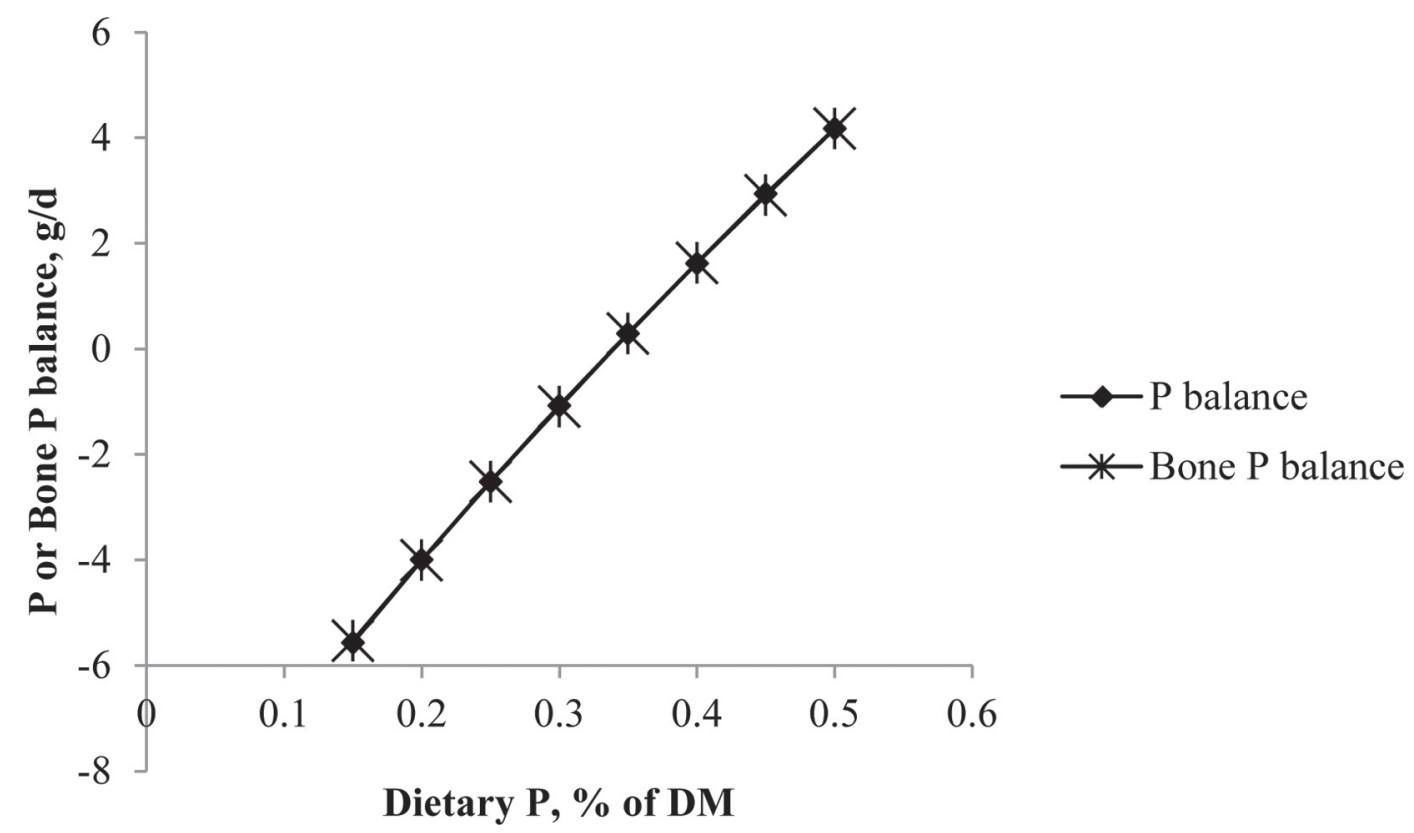

Figure 5. Phosphorus and bone $\mathrm{P}$ balance in response to varied dietary $\mathrm{P}$ (\% of DM) as predicted by the model using the parameters in Table 4. The milk yield $(30 \mathrm{~kg} / \mathrm{d})$ and proportions of phytate $\mathrm{P}$, organic and inorganic $\mathrm{P}(33.2,22.3$, and $44.5 \%$, respectively) were held constant as dietary P (\% of DM) varied. Dry matter intake was set to $23 \mathrm{~kg} / \mathrm{d}$. Slopes for P balance and bone P balance are 27.78 and $27.69 \mathrm{~g} / \%$.

the rumen. Increasing the proportion of phytate in the diet from $20 \%$ of total $\mathrm{P}$ to $50 \%$ resulted in a $0.5 \mathrm{~g} / \mathrm{d}$ reduction in $\mathrm{P}$ balance regardless of the amount of $\mathrm{P}$ in the diet (Figure 6). Based on these observations, one must conclude that the amount of phytate in the diet is likely of little relevance to maintaining $\mathrm{P}$ balance in the animal for diets similar to those used in this work, although one cannot rule out a greater role for some ingredients or conditions.

\section{Sensitivity Analysis}

Results of global sensitivity analysis are presented in Table 6. In contrast to local sensitivity analysis in which the sensitivity coefficients represent the change in the response variable resulting from a unit change in a single driving variable, global analysis provides an assessment of the proportion of variation in an output explained by each driving variable given a data set con-

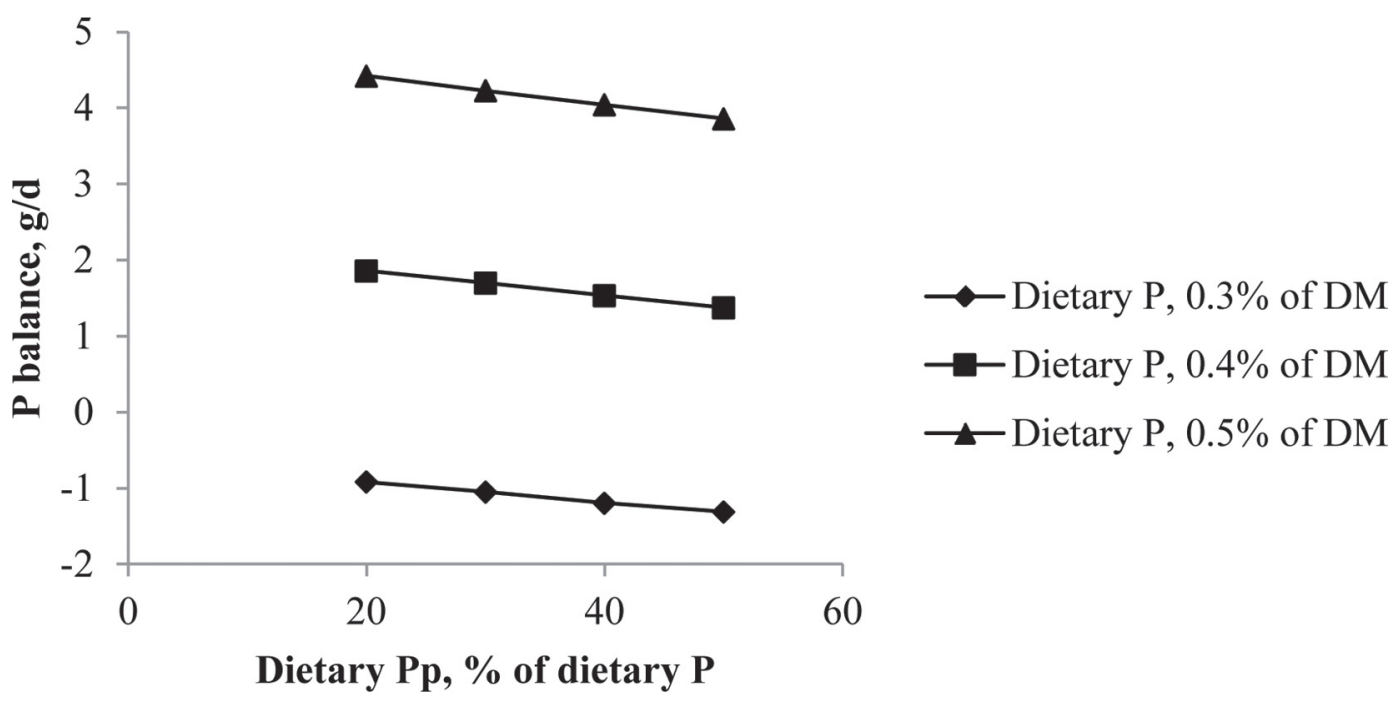

Figure 6. Phosphorus balance in response to varied dietary P (\% of DM) and phytate content (\% of dietary $\mathrm{P}$ ) as predicted by the model using the parameters in Table 4 . Milk yield was held constant as dietary $\mathrm{P}$ and phytate content varied. Dry matter intake was set to $23 \mathrm{~kg} / \mathrm{d}$. 
taining a large population of simulations conducted with random changes in all the driving variables of interest. As can be seen from this table, most model predictions had the greatest sensitivity to the concentration of total $\mathrm{P}$ in the diet regardless of $\mathrm{P}$ composition with the exceptions of the pool size of $\mathrm{Pp}$, the flow of $\mathrm{Pp}$ to the SI, the flow of Pp to the LI, and fecal excretion of Pp, all of which were more responsive to the proportion of $\mathrm{Pp}$ in the diet. Phosphorus balance was approximately equally responsive to dietary $\mathrm{Pp}$ and $\mathrm{Pi}$. The enhanced sensitivity to dietary $\mathrm{Pt}$ compared with the form of the $\mathrm{P}$ in the diet reflects the extensive catabolism of at least dietary Pp.

Fluxes were generally much less sensitive to the 10 model parameters that define the major components of the model, underscoring the importance of precise and accurate definition of model inputs when attempting to derive model parameters. Given the sequential nature of many of the equations, it is not surprising that parameters defining upstream degradation of $\mathrm{Pp}$ and $\mathrm{Po}$ in the rumen have an effect on quite a few fluxes. The other parameter that is quite important for many portions of the model is the rate constant for absorption of Pi from the SI.

The fluxes of $\mathrm{Pi}$ were insensitive to the ruminal $\mathrm{Pp}$ degradation rate constant $\left(R_{\mathrm{PpRum}, \mathrm{PiRum}}\right)$, which likely reflects the model structure with a single molecule of $\mathrm{Pi}$ being released from $\mathrm{Pp}$ upon degradation and the remainder of the $\mathrm{Pp}$ molecule transferred to the $\mathrm{Po}$ pool as IP5. As noted above, the rate of degradation of Po is much less than Pp and thus Po degradation would be the rate-limiting step for release of $\mathrm{Pi}$ in the rumen, which is consistent with the observed sensitivity of the $\mathrm{Pi}$ pool to the rate of degradation of Po.

Blood and bone $\mathrm{P}$, the latter reflected by $\mathrm{P}$ balance, were both sensitive to the parameters associated with $\mathrm{Pi}$ absorption from the SI and LI, P secretion into the rumen, and the rate constant for bone synthesis. As can be seen from Figure 1, these fluxes are the largest, and thus most influential ones in terms of $\mathrm{P}$ entry, storage, and excretion. Thus it is not surprising that they have significant influence on the blood and bone pool sizes.

\section{CONCLUSIONS}

The data were adequate to parameterize the digestive elements of the model with good precision, and the model structure appears to be appropriate given the lack of significant mean and slope bias. Some predictions had large RMSPE on a percentage basis, but the absolute errors approximated the expected variation associated with making the animal measurements. Phytate is greater than $90 \%$ available in the animal, but surprisingly, nonphytate organic $\mathrm{P}$ was not digested in

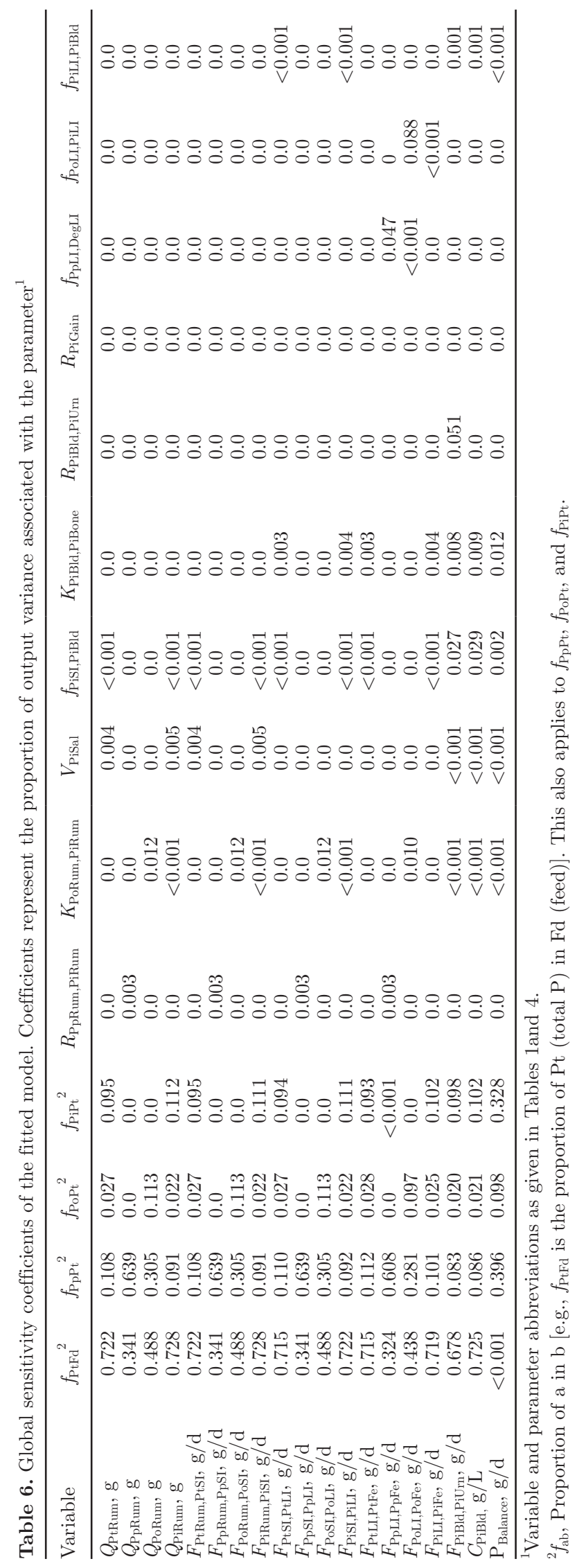


the SI although it was extensively degraded in the rumen and LI. Phosphorus release from phytate appears to be much faster than degradation of lower inositol phosphate molecules, and thus the rate-limiting step is not at phytase. As previously observed, the LI absorbs $15 \%$ of the $\mathrm{Pi}$ supply available in that compartment. Phosphorus balance is primarily regulated by changes in absorption rate from the SI and recycling of blood $\mathrm{Pi}$ to the rumen, and these fluxes are configured to absorb much more $\mathrm{P}$ than required and recycle the unused portion to the rumen. Urinary P excretion plays essentially no role in regulating $\mathrm{P}$ balance in bovine. Note that although the model explained the data used with no apparent bias, this does not guarantee that the model parameters are valid for all conditions. As additional data become available, it will become apparent whether this model truly has merit.

\section{ACKNOWLEDGMENTS}

Funding for this work was provided by USDA-AFRI grant \#2009-55206-05267s, by the Virginia Agricultural Experiment Station and the Hatch Program of the National Institute of Food and Agriculture, USDA. The authors acknowledge Partha Ray (Department of Dairy Science, Virginia Polytechnic Institute and State University, Blacksburg) for providing help in data collation and technical advice. The critical comments of Robin White (Department of Dairy Science, Virginia Polytechnic Institute and State University) are gratefully acknowledged.

\section{REFERENCES}

Anderson, R. J. 1915. The hydrolysis of phytin by the enzyme phytase contained in wheat bran. J. Biol. Chem. 20:475-482.

Biddy, J., and H. Toutenberg. 1977. Prediction and improved estimation in linear models. Wiley, Chichester, UK.

Blomstrand, R. 1955. The intestinal absorption of phospholipids in the rat. Acta Physiol. Scand. 34:147-157.

Bravo, D., F. Meschy, C. Bogaert, and D. Sauvant. 2002. Effects of fungal phytase addition, formaldehyde treatment and dietary concentrate on ruminal phosphorus availibility. Anim. Feed Sci. Technol. 99:73-95.

Dias, R. S., E. Kebreab, D. M. Vitti, A. P. Roque, I. C. Bueno, and J. France. 2006. A revised model for studying phosphorus and calcium kinetics in growing sheep. J. Anim. Sci. 84:2787-2794.

Dias, R. S., S. Lopez, R. M. Patino, T. S. Silva, J. C. Silva Filho, D. M. Vitti, M. R. Pecanha, E. Kebreab, and J. France. 2011. An extended model of phosphorus metabolism in growing ruminants. J. Anim. Sci. 89:4151-4162.

Durand, M., and R. Kawashima. 1980. Influence of minerals in rumen microbial digestion. Pages $375-408$ in Digestive physiology and metabolism in ruminants. Y. Ruckebusch and P. Thivend, ed. AVI Publishing Company Inc., Westport, CT.

Duskova, D., R. Dvorak, V. Rada, J. Doubek, and M. Marounek. 2001. Concentration of phytic acid in faeces of calves fed starter diets. Acta Vet. Brno 70:381-385.

Efron, B. 2012. Bayesian inference and the parametric bootstrap. Ann. Appl. Stat. 6:1971-1997.
Ellis, L. C., and A. D. Tillman. 1961. Utilization of phytin phosphorus in wheat bran by sheep. J. Anim. Sci. 20:606-607.

Feng, X., K. F. Knowlton, A. D. Dietrich, and S. Duncan. 2013. Effect of abomasal ferrous lactate infusion on phosphorus absorption in lactating dairy cows. J. Dairy Sci. 96:4586-4591.

Feng, X., E. Ronk, M. Hanigan, K. Knowlton, H. Schramm, and M. McCann. 2015. Effect of different dietary phosphorus on intestinal phosphorus absorption on growing Holstein steers. J. Dairy Sci. 98:3410-3416.

Firkins, J. L., M. S. Allen, B. S. Oldick, and N. R. St-Pierre. 1998. Modeling ruminal digestibility of carbohydrates and microbial protein flow to the duodenum. J. Dairy Sci. 81:3350-3369.

Geisert, B. G., G. E. Erickson, T. J. Klopfenstein, C. N. Macken, M. K. Luebbe, and J. C. MacDonald. 2010. Phosphorus requirement and excretion of finishing beef cattle fed different concentrations of phosphorus. J. Anim. Sci. 88:2393-2402.

Guyton, A. D., J. M. McKinney, and K. F. Knowlton. 2003. The effect of steam-flaked or dry ground corn and supplemental phytic acid on phosphorus partitioning and ruminal phytase activity in lactating cows. J. Dairy Sci. 86:3972-3982.

Harrison, J., K. F. Knowlton, B. James, M. D. Hanigan, C. Stallings, and E. Whitefield. 2012. Case study: National survey of barriers related to precision phosphorus feeding. Prof. Anim. Sci. 28:564568

Hill, B. E., S. L. Hankins, J. F. Kearney, J. D. Arseneau, D. T. Kelly, S. S. Donkin, B. T. Richert, and A. L. Sutton. 2002. Effects of feeding low phytic acid corn and phytase on phosphorus balance in lactating dairy cows. J. Dairy Sci. 85(Suppl. 1):44.

Hill, S. R., K. F. Knowlton, E. Kebreab, J. France, and M. D. Hanigan. 2008. A model of phosphorus digestion and metabolism in the lactating dairy cow. J. Dairy Sci. 91:2021-2032.

Jarrett, J. P., J. W. Wilson, P. P. Ray, and K. F. Knowlton. 2014. The effects of forage particle length and exogenous phytase inclusion on phosphorus digestion and absorption in lactating cows. J. Dairy Sci. $97: 411-418$.

Kebreab, E., M. A. Shah, D. E. Beever, D. J. Humphries, J. D. Sutton, J. France, and I. Mueller-Harvey. 2005. Effects of contrasting forage diets on phosphorus utilisation in lactating dairy cows. Livest. Prod. Sci. 93:125-135.

Kincaid, R. L., and M. Rodehutscord. 2005. Phosphorus metabolism in the rumen. Pages 187-194 in Nitrogen and Phosphorus Nutrition of Cattle. Reducing the Environmental Impact of Cattle Operations. E. Pfeffer and A. N. Hristov, ed. CABI Publishing, Wallingford, UK

Knowlton, K. F., and J. H. Herbein. 2002. Phosphorus partitioning during early lactation in dairy cows fed diets varying in phosphorus content. J. Dairy Sci. 85:1227-1236.

Knowlton, K. F., M. S. Taylor, S. R. Hill, C. Cobb, and K. F. Wilson. 2007. Manure nutrient excretion by lactating cows fed exogenous phytase and cellulase. J. Dairy Sci. 90:4356-4360.

Liao, S. F., A. K. Kies, W. C. Sauer, Y. C. Zhang, M. Cervantes, and J. M. He. 2005. Effect of phytase supplementation to a low- and a high-phytate diet for growing pigs on the digestibilities of crude protein, amino acids, and energy. J. Anim. Sci. 83:2130-2136.

Morse, D., H. H. Head, and C. J. Wilcox. 1992. Disappearance of phosphorus in phytate from concentrates in vitro and from rations fed to lactating dairy cows. J. Dairy Sci. 75:1979-1986.

NRC. 2001. Nutrient Requirements of Dairy Cattle. 7th rev. ed. The National Academies Press, Washington, DC.

Park, W. Y., T. Matsui, and H. Yano. 2002. Post-ruminal phytate degradation in sheep. Anim. Feed Sci. Technol. 101:55-60.

Powell, M. J. D. 1970. A Fortran subroutine for solving systems of nonlinear algebraic equations. Pages 87-114 in Numerical Methods for Nonlinear Algebraic Equations. P. Rabinowitz, ed. Gordon and Breach Science Publishers, London, UK.

Puggaard, L., N. B. Kristensen, and J. Sehested. 2011. Effect of decreasing dietary phosphorus supply on net recycling of inorganic phosphate in lactating dairy cows. J. Dairy Sci. 94:1420-1429.

Ray, P. P., J. Jarrett, and K. F. Knowlton. 2013. Effect of dietary phytate on phosphorus digestibility in dairy cows. J. Dairy Sci. 96:1156-1163. 
Ray, P. P., C. Shang, R. E. Pearson, and K. F. Knowlton. 2012. Disappearance of infused phytate from the large intestine of dairy heifers. J. Dairy Sci. 95:5927-5935.

Saltelli, A., S. Tarantola, and K. P. S. Chan. 1999. A quantitative mode independent method for global sensitivity analysis of model output. Technometrics 41:39-56.

Smith, V. H., G. D. Tilman, and J. C. Nekola. 1999. Eutrophication: Impacts of excess nutrient inputs on freshwater, marine, and terrestrial ecosystems. Environ. Pollut. 100:179-196.

Ternouth, J. H. 1968. Changes in the thiosulphate space and some constituents of the blood of sheep after feeding. Res. Vet. Sci 9:345-349.
Verbic, J., X. B. Chen, N. A. MacLeod, and E. R. Ørskov. 1990. Excretion of purine derivatives by ruminants. Effect of microbial nucleic acid infusion on purine derivative excretion by steers. J. Agric. Sci. 114:243-248.

Vitti, D. M., E. Kebreab, J. B. Lopes, A. L. Abdalla, F. F. De Carvalho, K. T. De Resende, L. A. Crompton, and J. France. 2000. A kinetic model of phosphorus metabolism in growing goats. J. Anim. Sci. 78:2706-2712.

Wu, Z., L. D. Satter, and R. Sojo. 2000. Milk production, reproductive performance, and fecal excretion of phosphorus by dairy cows fed three amounts of phosphorus. J. Dairy Sci. 83:1028-1041.

\section{Appendix}

Table A1. Phosphorus flow data for Feng et al. (2011, personal communication) ${ }^{1}$

\begin{tabular}{|c|c|c|c|c|c|c|c|c|}
\hline \multirow[b]{2}{*}{ Item } & \multicolumn{4}{|c|}{$\mathrm{P}$ supply, ${ }^{2} \%$ of requirement } & \multirow[b]{2}{*}{$\mathrm{SE}$} & \multicolumn{3}{|c|}{$P$-value ${ }^{3}$} \\
\hline & 50 & 80 & 110 & 140 & & Treatment & Linear & Quadratic \\
\hline Intake, $\mathrm{g} / \mathrm{d}$ & 42.7 & 41.5 & 45.4 & 43.9 & 2.85 & 0.69 & 0.50 & 0.96 \\
\hline Ileal TP flow, g/d & 23.8 & 39.9 & 49.4 & 85.9 & 5.76 & $<0.001$ & $<0.001$ & 0.09 \\
\hline Net disappearance of $\mathrm{P}$ from LI, $\mathrm{g} / \mathrm{d}$ & 6.25 & 12.3 & 15.1 & 23.7 & 3.75 & 0.08 & 0.02 & 0.74 \\
\hline Fecal TP, g/d & 17.5 & 27.7 & 34.4 & 62.3 & 3.26 & $<0.001$ & $<0.001$ & 0.002 \\
\hline TP balance, $\mathrm{g} / \mathrm{d}$ & -0.98 & 10.1 & 22.9 & 12.5 & 3.33 & 0.005 & 0.005 & 0.008 \\
\hline \multicolumn{9}{|l|}{ Inorganic $\mathrm{P}(\mathrm{Pi})$} \\
\hline Intake, g/d & 27.31 & 27.8 & 31.15 & 27.91 & 1.41 & 0.27 & 0.43 & 0.22 \\
\hline Ileal Pi flow, g/d & 8.19 & 16.2 & 27.4 & 52.9 & 3.40 & $<0.001$ & $<0.001$ & 0.03 \\
\hline Disappearance of Pi from LI, g/d & 0.06 & -1.64 & 6.36 & 15.4 & 2.64 & 0.01 & 0.004 & 0.09 \\
\hline Fecal Pi, g/d & 8.13 & 17.8 & 21.0 & 37.6 & 4.03 & 0.003 & $<0.001$ & 0.29 \\
\hline Serum $\mathrm{Pi}, \mathrm{mg} / \mathrm{dL}$ & 3.53 & 5.87 & 6.64 & 6.48 & 0.38 & 0.008 & 0.003 & 0.03 \\
\hline
\end{tabular}

${ }^{1}$ X. Feng, J. P. Jarrett, P. P. Ray, L. Karpinski, B. Willing, and K. F. Knowlton (2011, personal communication). LI = large intestine.

${ }^{2}$ Cows were abomasally infused with $0,20.2,40.2$, and $60.3 \mathrm{~g} / \mathrm{d}$ inorganic $\mathrm{P}$ (Pi) solution to supply 50, 80, 110, and 140\% of their calculated P requirement.

${ }^{3} P$-values for treatment, linear, and quadratic effects. 